\title{
The Cerro Medanoso draa (Atacama, Chile) and its importance in the study of desert geomorphology
}

\author{
El draa Cerro Medanoso (Atacama, Chile) y su importancia en el \\ estudio de geomorfología de desierto
}

\author{
J.F. Araya-Vergara ${ }^{1} \&$ Ricardo Vilaró ${ }^{2}$
}

\begin{abstract}
This work presents a morphological analysis of the Cerro Medanoso draa (Atacama Marginal Desert) and the type of contact with the desert pavements of neighboring glacis and piedmont. This study is based on an analysis of aerial photos, and a digital elevation model. Aster GDEM was used as a basis for the survey. Fieldwork observations covered two principal zones: the nucleus and the envelope. Following fieldwork, analysis of satellite imagery was conducted. It was possible to identify the following phases of formation: construction of a stellate nucleus, merging of the eastern envelope, merging of the southern envelope and merging of a complex western envelope. The southeastern facing envelope is much bigger than the northwestern facing one. Consequently, the construction of the complex draa is asymmetric. The correlation of this megadune with similar star and compound draas to other deserts in the world indicates that the closest analogue exists in Namibia, but without merging signals between the envelope and the nucleus. Star draas observed in other deserts exhibit a lack of this envelope. With reference to the neighboring piedmont, the beginning of its deflation must be necessarily correlative to the initial construction of the nuclear twin star draa. The later deflation could be responsible for the pulses, which formed the envelope. Therefore, the neighboring desert pavement and the draa are correlative landforms, which represent a very long time formation, in an important part of the desert history, as evidenced by the cited and referenced research works.
\end{abstract}

Keywords: desert geomorphology, draa, glacis, desert pavement

\section{RESUMEN}

Se muestra un análisis del draa Cerro medanoso (Desierto Marginal de Atacama) y su tipo de contacto con el pavimento de desierto del glacis y piedmont vecinos. El trabajo previo se apoyó en fotos aéreas. El modelo de elevación digital Aster Gdem sustentó el levantamiento topográfico. La observación de terreno cubrió dos zonas principales: el núcleo y la envoltura. Después del trabajo de campo se usó imágenes de satélite. Se deduce las siguientes fases en la formación de este draa: construcción de un núcleo estrellado, fusión de la envoltura oriental, fusión de la envoltura sur y fusión de la envoltura occidental compleja. La envoltura de exposición suroeste es más maciza que la de exposición noroeste. Consecuentemente, la construcción del draa complejo es asimétrica. La correlación de esta megaduna con draas estrellados y compuestos similares de otros desiertos del mundo, indica que el tipo más cercano existe en Namibia, pero sin señales de fusión entre la envoltura y el núcleo. Draas estrellados observados en otros desiertos carecen de envoltura. En relación con el piedmont y glacis vecinos, el comienzo de su deflación debe ser necesariamente correlativo a la construcción inicial del draa nuclear doblemente estrellado. La deflación tardía puede ser responsable de los pulsos que formaron la envoltura. Luego, el pavimento de desierto vecino y el draa son formas correlativas, que representan un tiempo muy largo de formación, en una parte importante de la historia del desierto, como se evidencia en los trabajos de investigación citados y referenciados.

Palabras clave: geomorfología de desierto, draa, glacis, pavimento de desierto

Recibido el 24 de marzo de 2016; aceptado el 28 de junio de 2016.

1 Departamento de Geografía, Universidad de Chile, Av. Portugal 84, Santiago, jaraya@uchilefau.cl

2 Escuela de Postgrado. Facultad de Arquitectura y Urbanismo 


\section{INTRODUCTION}

The Arabic word draa means "arm" and describes the largest ridge of gigantic dunes (WILSON 1972; LANCASTER 2004). This landform is a megadune (WARREN \& ALLISON 1998) and sometimes appears as a compound or complex landform (BREED \& GROW 1979, in LANCASTER 2004). Its spacing or larger axis exceeds $500 \mathrm{~m}$ and its height reaches 200 or $300 \mathrm{~m}$ (LANCASTER 2004).

A first description of Cerro Medanoso indicates that this landform "in the northeastern part (of Central Atacama) is a rock-cored mountain of dune sand that reaches a height of $550 \mathrm{~m}$ above the alluvial plain. The mountain stands like a barrier at the east end of a long chain of dunes..." (SEGERSTROM 1967: 312). Other former works lack precise morphological or genetic information about this landform. Nevertheless, and taking into account the possible relationship between alluvial plains supplying sands and eolian landforms, some other papers on the Atacama Desert are important, because of their reference to desert pavement. In this manner, BRÜGGEN (1951) exposes a genetic model for this feature, defined as "costra de protección" or hamada, terms considered synonyms of the desert pavement in present terminology. More recently, BAILEY et al. (2007) have shown examples of desert pavements and a model of the process of deflation due to removal of fine material by wind, thereby producing an armored surface texture, which remains on the landscape. This model is similar to that shown by BRÜGGEN (1951). On the other hand, a compilation discussed by CLARKE (2006) indicates that the aridity in the Atacama Desert is very old. The Cenozoic, Neogene and Quaternary landforms all show climatic oscillations of a constant hyperarid environment. Research on alluvial fans in the Coastal Cordillera indicates that their masses are relict (HARTLEY et al. 2005). However, the observations on climatic and geomorphic interaction on alluvial fans in this desert suggest that the processes on their surfaces have not been static at all (HAUG et al. 2010). Several infrequent hydrological thresholds are possible on the surface of alluvial fans, even though their actual influence on their surfaces is not well known.

Therefore, the aim of this work is to carry out a morphological analysis of the isolated Cerro Medanoso draa and to indicate the type of contact with the desert pavements of the neighboring landscapes, in order to understand its importance in the geomorphological evolution of the desert.

\section{MATERIALS AND METHODS Material studied}

Why the selection of Cerro Medanoso? It is an isolated draa at the bottom of a basin occupied by alluvial fans and glacis (Figs. 1 and 2), $20 \mathrm{~km}$ from the sea at the end of the Southern Erg, in the Atacama Marginal Desert (ARAYA-VERGARA 2001). The contact between the glacis and the outer draa slope is sharp. The surface of the glacis is composed of desert pavement. The distance between the proximal part of the set of alluvial fans and the foot of the draa is $\sim 3-6 \mathrm{~km}$. At the same time, the features of the draa indicate the effect of winds blowing from different directions. Therefore, the spatial relationships between the mega-dune and the set of alluvial fans and glacis in the depression suggest correlative landforms.

\section{Descriptive terminology applied to a star or compound draa}

There are different terms in order to describe this type of draa. A simple star draa is a pyramidal landform with three or four arms radiating from a central peak; the crest of each arm is generally sinuous (LANCASTER 1989) and defines the crestline (NIELSON \& KOCUREK 1987). This element appear sometimes as "Chinese Wall" (WARREN 2013) where the crest is extremely sharp. 
Elsewhere, the special reversal features generate flat tops because of reversing winds (BRISTOW et al. 2010). There are two types of arms according to their size order (range in height): prominent or principal arms and diffuse secondary arms, which terminal feature is a defect (BEVERIDGE et al. 2006). The relationship between two different star arms or between one star arm and neighboring linear dune results of lateral linking, producing linked defects (BOURKE et al. 2009). In the slope of the arms a short wave roughness frequently appears composed of very elongated barchans or upsiloidal dunes in the direction of the slope, forming a set of parallel features, named organ pipes by ARAYA-VERGARA (2001). Elsewhere, these features display a tuningfork juncture (BEVERIDGE et al. 2006) Nevertheless, the general term used for them is transverse ridge by BOURKE et al. (2003), following the approach by BULLARD et al. (1995) to propose specific categories (simple, sinuous, forked, feathered and networked). If a star draa is closely associated with other types of draa, superimposed landforms appear over the periphery of the star draa, following a superimposition surface, which presents an angle-of-climb (MOUNTNEY \& HOWELL 2000). These associated landforms are generally transverse draa or linear draa (MOUNTNEY 2003), which are mergers that produce a break-up of the downwind dune (KOCUREC \& EWING 2005; BOURKE et al. 2009). Therefore, a star draa surrounded by peripheric mergers is a compound or complex draa if it contains the described features. A synthetical name for the set of surrounding mergers shaping a fringe is envelope.

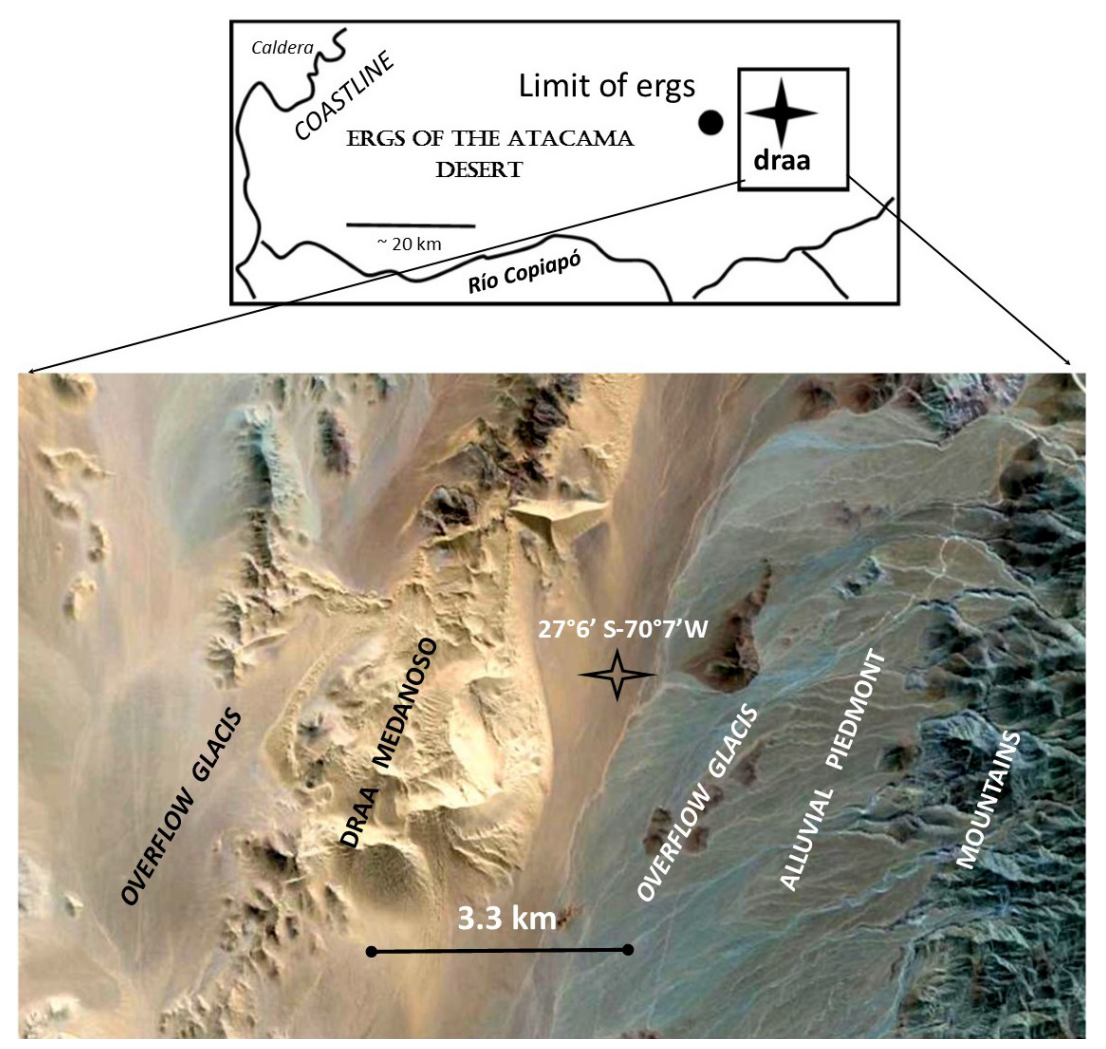

Fig. 1. Geomorphological location

Fig. 1. Ubicación geomorfológica 


\section{Procedures}

The preliminary and general observation of the draa and glacis, before the fieldwork, was made possible by means of aerial photos at a scale of 1: 70.000 and dating from 1955 and 1997. The topographic survey of the draa was carried out by means of the digital elevation model, Aster Gdem, which supplied elevations with reliable precision. The field observation covered two principal zones: the internal or nucleus, representing an original system of stellate draa and the outer envelope of peripheral draas (Fig. 3). In both zones, the terms used for the description of elements were those defined in the former paragraph. So, the orientation of arms, the slope orientation and morphology, location of central peaks, and morphological comparison between opposite slopes were defined. For comparison between opposite slopes, the experiences of ZIMBELMAN (2010) on the degree of symmetry between opposite slopes and the conceptual model by BUBENZER $\&$ BOLTEN (2008) on the influence of counter operating winds were useful. Also, knowledge of the structure of the desert pavement derives from observations both in the eastern and western proximities of the draa, prioritizing the search for ventifacts.

For a general description of sand, an isolated and discrete sample is a proxy of the outer zone or envelope. The grain size analysis consisted of sieving and microscopic viewing (COMPTON 1962; PETTIJOHN et al. 1972). The techniques of POWERS (1953) and STEFAN (2007) facilitated the grain roundness observation. The particle surface texture was based on the methods by KRUMBEIN \& PETTIJOHN (1938), SOUTENDAM (1967) and LÓKI \& CSERHÁTI (2006). The grain color

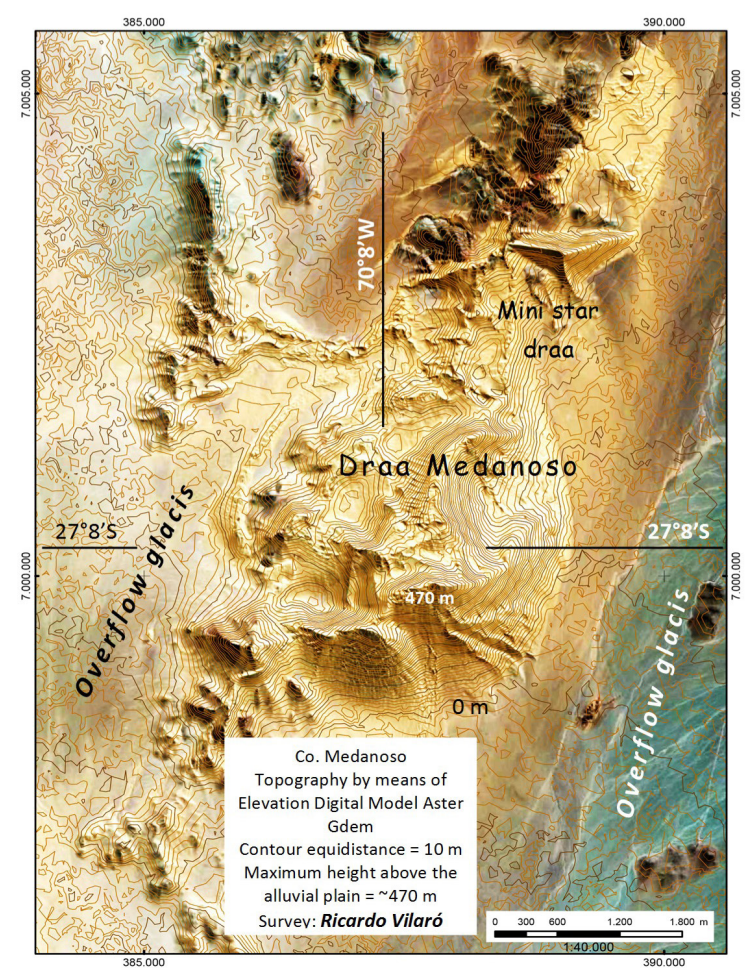

Fig. 2. Medanoso topography

Fig. 2. Topografía del Medanoso 
was measured in the laboratory under standardized light (MUNSELL COLOR COMPANY INC. 1975), in order to compute the Redness Rating according to HURST (1977). The experiences of LUCKE et al. (2014) indicate that this index decreases with increasing redness, with extreme values of 61 and 8 for Mediterranean soils. In addition, some weathering features were observed (NGUER \& ROGNON 1989). Finally, the use of a 3500 gauss magnet rendered possible the approximate separation of magnetic sands.
In order to reach more precision in the slope analysis (Fig. 2), and after fieldwork observations, the analysis continued using Google Earth images, both at general and at detailed scales (e.g., 1: 10.000 or 1: 5.000). The models of LANCASTER (1989) for star dune formation, KOCUREK \& EWING (2005) about merging and lateral linking on dunes, and WERNER (1995) on computer simulation for star dunes, were used as fundamentals of analysis and interpretation.

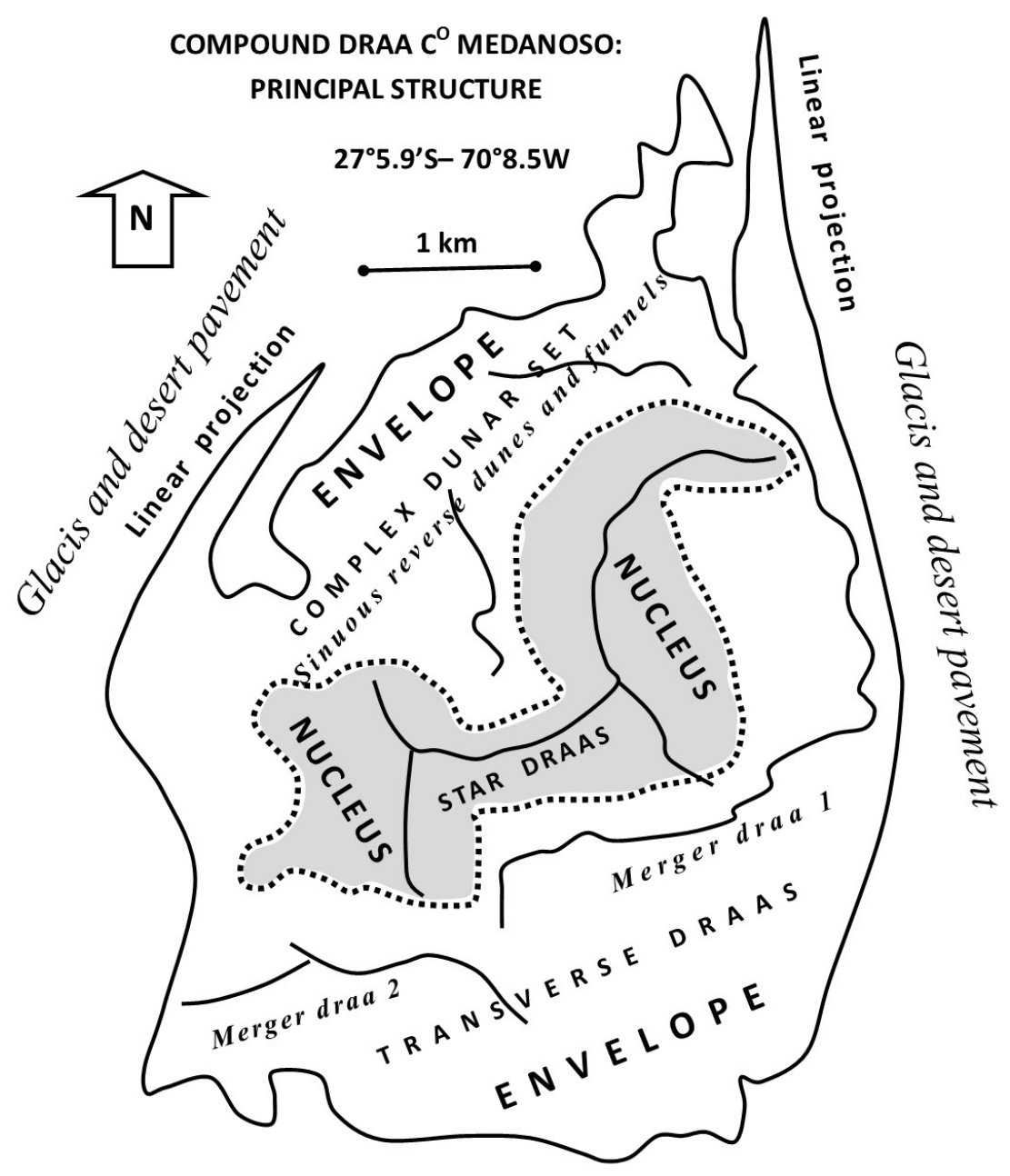

Fig. 3. Principal structure

Fig. 3. Estructura principal 


\section{RESULTS}

\section{General morphology}

Principal draa structure (Figs. 2 and 3; Table 1)

The draa shows two principal zones: the nucleus and the envelope.

The nucleus contains two star draas each of which has three arms. A common arm connects these stellate landforms, constituting a compact unit of two star draas. Therefore, the nucleus is a compound star draa.

The envelope is the outer dune set around the nucleus. It contains two zones: two transverse draas on the SE side and a complex dune set on the NW side. Two appendixes of this envelope are northward projections of linear dunes (linear projections). Hence, this envelope is also a compound landform.

Consequently, the contiguity of the nucleus and the envelope clearly conform a complex draa.

Principal structure of the alluvial fans and glacis (Figs. 1, 2; Table 1)

The bottom of the Cerro Medanoso depression shows two sets of landforms. The eastern section is a piedmont composed by alluvial fans in its proximal section and overflow glacis in its distal section. Both the alluvial fans and the glacis exhibit desert pavement on their surfaces. In exchange, the western section is essentially a glacis, but its surface also contains desert pavement.

TABLE 1: MORPHOMETRIC PROPERTIES OF THE DRAA AND THE NEIGHBORING GLACIS AND ALLUVIAL FANS

TABla 1: Propiedades MORFométricAS del dRAA Y DEL GLACIS Y CONOS ALUVIALES Vecinos

\begin{tabular}{|c|c|c|}
\hline $\begin{array}{l}\text { GLACIS AND } \\
\text { ALLUVIAL FANS }\end{array}$ & COMPOUND DRAA & \\
\hline $\begin{array}{l}\text { Area }=302 \mathrm{~km}^{2}, 19.5 \\
\text { times greater than the } \\
\text { draa area }\end{array}$ & $\begin{array}{l}\text { Maximum length }=5.2 \mathrm{Km} . \text { Max. width }=3.3 \mathrm{Km} \\
\text { glacis-alluvial fan area) }\end{array}$ & Area $=15.5 \mathrm{Km}^{2}(4.8 \%$ of \\
\hline \multirow{2}{*}{$\begin{array}{l}\text { Width }=3-6 \mathrm{~km} . \\
\text { Slope angle: eastern } \\
\text { (piedmont) }=3-4^{\circ} ; \\
\text { western glacis }=1-2^{\circ}\end{array}$} & Nucleus (inner star draas) & Envelope (outer draas) \\
\hline & $\begin{array}{l}\underline{\text { Area }}=3.7 \mathrm{~km}^{2}(25.5 \% \text { of the complex draa }) . \\
\underline{\text { Heights }} \text {, Raster Model Gdem: central peak } 1 \text { of } \\
\text { star NE }=\sim 370 \mathrm{~m} \text {; central peak } 2 \text { of star } \mathrm{SW}=\sim \\
300 \mathrm{~m} . \underline{\text { Principal arms: Azimuths }}\left({ }^{\circ}\right): \text { star } 1=0, \\
140 \text { and } 240 ; \text { star } 2=90,180 \text { and } 335 . \underline{\text { Slope }}\left({ }^{\circ}\right) \\
=17-24^{\circ} . \underline{\text { Lengths }}(\mathrm{km}): \text { star } 1=0.77,0.35 \text { and } \\
0.51 ; \text { star } 2=0.52,0.29 \text { and } 0.67 .\end{array}$ & $\begin{array}{l}\text { Area }=10.8 \mathrm{Km}^{2}(74.5 \% \text { of } \\
\text { the compound draa). Heights: } \\
\text { central peak of transverse draa } \\
1=\sim 430 \mathrm{~m} \text {; transverse draa } 2= \\
\sim 360 \mathrm{~m} \text {. } \\
\text { Superimposition surface } \\
\text { (bedform climb angle): } \sim 17 \\
\text { and } \sim 22^{\circ} \text { (assumed) }\end{array}$ \\
\hline
\end{tabular}




\section{Analysis of the draa}

The nucleus (Figs. 2, 3 and 4; Tables 1 and 2)

\section{Morphology of the stellate system compound}

The connection between the two threearmed stars is by means of lateral linking between the principal arms. However, the system also includes four secondary arms. The spaciousness of the principal unconnected arms inter draa is 0.87 and $1.18 \mathrm{~km}$. The intersection of arms defines the hierarchy and number of peaks. Their mention here concerns only the central peaks of the stars 1 and 2 (Table 1). The existence of secondary arms defines at least three secondary peaks. The azimuths of the principal arms and the setting of the corresponding central peaks suggest the operation of at least four principal wind directions in the morphogenesis: NW, NE, SW and SE or SSE. Damage on the principal and secondary arms are pointed features suggesting that the arm lengthening has finished as a free process, non-forced by the inner slope of the envelope, which slopes do not recover from defects. In these type of environments, some defects of small secondary arms are inter linked, suggesting a possible territoriality in the peripheral nuclear zone.

\section{Arm crestlines}

The crestline of the principal and secondary arms is sharp, commonly adopting the form like the Great Wall of China. This type of crestline presents frequent crest bifurcations and the development of a flat top between the corresponding limiting crests. Moreover, the crestline of the arms is sinuous. This sinuosity suggests an effect from alternate reversing winds in the corresponding crestal changes, both at the time and from time to time. The cases of a Chinese wall (CHW) represent the influence of simultaneous convergent winds, without important differences between stoss and lee slopes. Nevertheless, the existence of sinuous crestlines does not necessarily exclude the presence of a CHW. The lack of a CHW seems to represent a more accentuated operation of reversing winds, producing a major effectiveness in the mechanisms of stoss and lee arm slopes.

The revised crestline features suggest their direct relationship with the degree of symmetry between the arm slopes. This attribute includes the slope profile and its slope angle. Therefore, well developed sinuosity and a less development of a CHW insinuate a trend to alternate the reversal behavior of asymmetric slopes. In exchange, the permanence of welldeveloped CHW reflects the stability of symmetrical slopes of the arm. Finally, the lack of a CHW suggests a more frequent and effective change of symmetry in the corresponding slopes. Therefore, the degree of displacement of crestlines is a function of the presence or absence of stoss or lee conditions in slopes.

\section{Arm slopes (Table 2)}

The slopes of the principal arms show transverse ridges, which adopt the general aspect of "organ pipes". This term has been adopted considering their similarity with the pipes of a musical instrument. Their form varies principally between the types nearly simple and nearly forked (tuningfork junctions). The geomorphological examination indicates that the forked types have elements of elongated upsiloidal dunes, because the junction between two ridges points up the slope in the distal part. In exchange, the simple cases frequently show that the ridges are elongated horns of barchans, evidenced by their connection with a crescestic original form in the proximal zone (low slope). On the other hand, the simple ridges without indication of features suggesting dune elongation are only linear landforms. Taking into account the dimensions shown in Table 2, these landforms are not simply small dunes, but important features, indicators of the stoss facing of the arm slopes. 


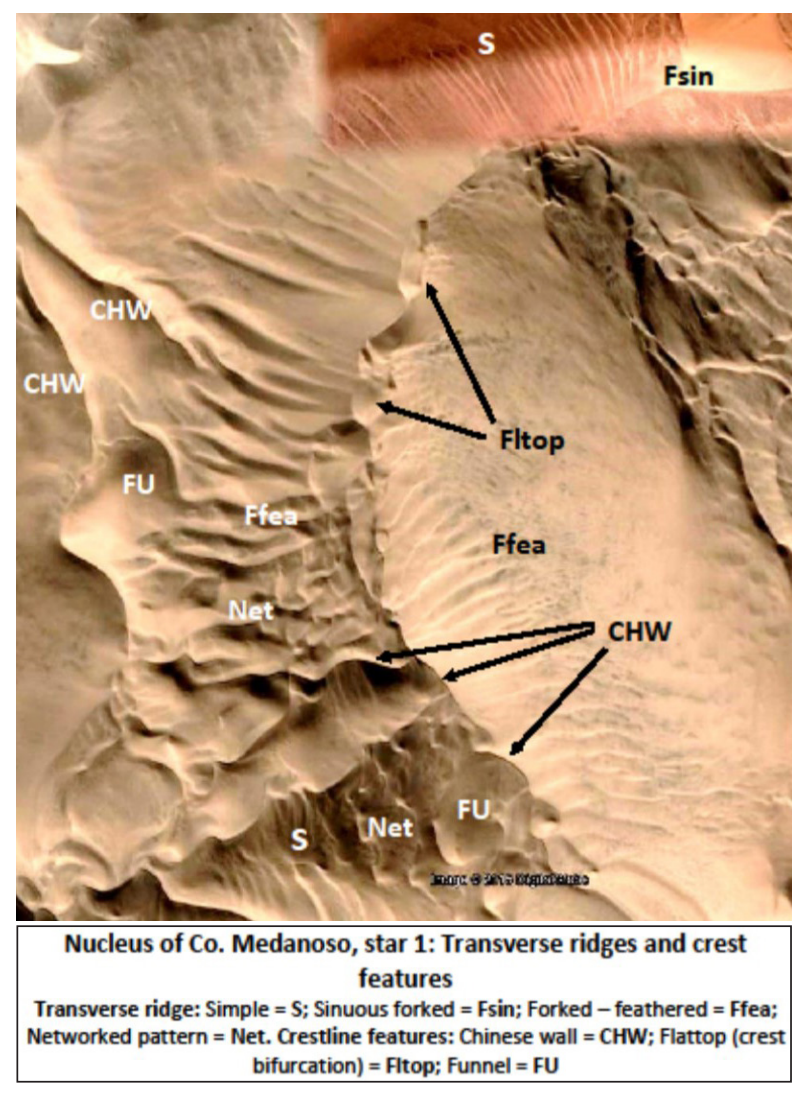

Fig. 4. Medanoso nucleus

Fig. 4. Núcleo del Medanoso

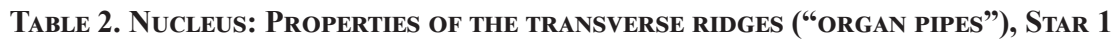

Tabla 2. Núcleo: Propiedades de los cordones transversales (“tubos de órgano"), ESTRELLA 1

\begin{tabular}{|c|c|c|c|c|}
\hline ARM & $\begin{array}{l}\text { SLOPE } \\
\text { FACING }\end{array}$ & TYPE & $\begin{array}{l}\text { WAVE LENGTH } \\
\text { IN CROSS } \\
\text { SECTION (M) }\end{array}$ & $\begin{array}{l}\text { TYPE AND SIZE OF DUNE } \\
\text { ELONGATION }\end{array}$ \\
\hline Star 1: $\operatorname{arm~N}$ & WNW & $\begin{array}{l}\text { Sinuous } \\
\text { forked }\end{array}$ & 49 & $\begin{array}{l}\text { Linear upsiloidal: arm length }= \\
220-225 \mathrm{~m} \text {; width between arms }= \\
53-39 \mathrm{~m}\end{array}$ \\
\hline Star 1: $\operatorname{arm~N}$ & $\mathrm{NNW}$ & Simple & $15-22$ & $\begin{array}{l}\text { Linear barchanic: horn length }= \\
173-184 \mathrm{~m} \text {; width between horns }= \\
17-27 \mathrm{~m}\end{array}$ \\
\hline Star 1: $\operatorname{arms} \mathrm{N}$ and $\mathrm{S}$ & ENE & $\begin{array}{l}\text { Forked } \\
\text { to nearly } \\
\text { feathered }\end{array}$ & 20 & $\begin{array}{l}\text { Linear upsiloidal: arm length }=127- \\
186 \text { m; width between arms }=14-28 \\
\mathrm{~m} . \text { Linear barchanic: horn length }= \\
156-174 \mathrm{~m} \text {; width between horns }= \\
14-38 \mathrm{~m}\end{array}$ \\
\hline $\begin{array}{l}\text { Arm of linking } \\
\text { between stars } 1 \text { and } 2\end{array}$ & $\mathrm{~S}$ & Simple & 20 & $\begin{array}{l}\text { Linear upsiloidal or barchanic: } \\
\text { length }=74-81 \mathrm{~m} \text {; width } 15-17 \mathrm{~m}\end{array}$ \\
\hline
\end{tabular}




\section{The envelope}

Southeast facing system (Figs 3 and 5, Tables 1 and 3)

This part of the envelope contains two transverse draas, which merge with the nucleus. The transverse draa 1 merges directly with the nucleus. The contact between the two landforms is a subterranean superposition surface (Table 1, Fig. 6). Jointly, the transverse draa 2 merges with the transverse draa 1, producing another subterranean superposition surface. A drift of sand fed by the northern end of the transverse draa 1 seems to be the cause of the linear projection developed toward the N. For both draas, the analysis concerns the slope defined as stoss, because it indicates the influence of SW and S formative winds.

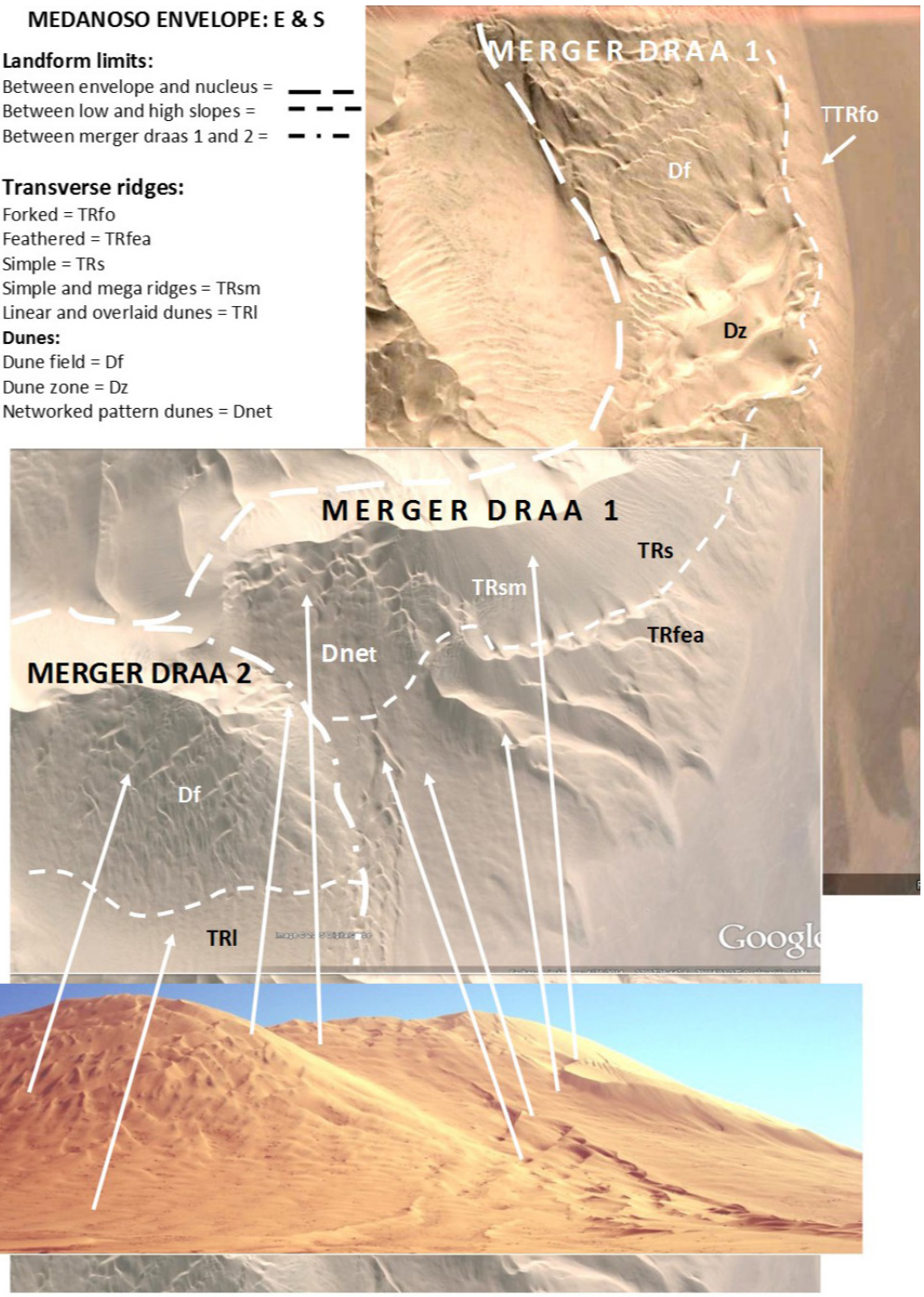

Fig. 5. Medanoso: envelopes $1 \& 2$

Fig. 5. Medanoso: envolturas 1 y 2 


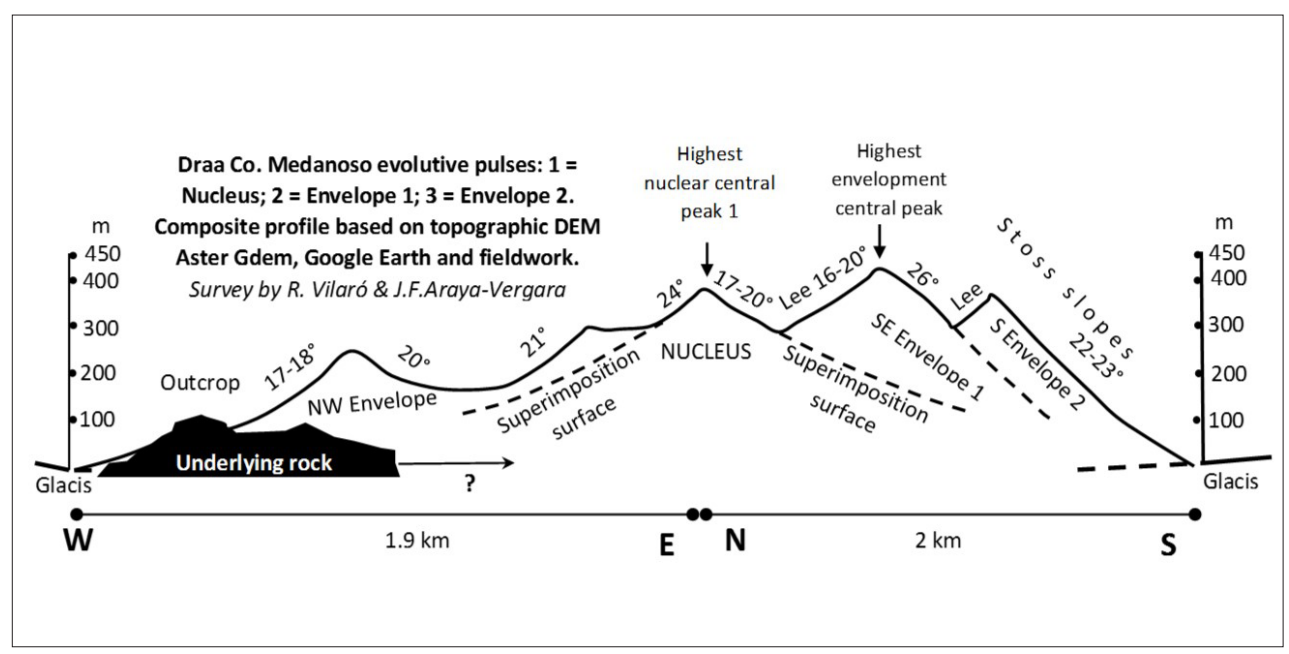

Fig. 6. Profile showing the formative pulses

Fig. 6. Perfil que muestra los pulsos formativos

The slope of the first merger draa 1, presents two zones: a low and a high stoss slope. The low zone is a residual slope. It shows only transverse ridges. Usually, its slope angle is bigger than the high slope. On the other side, the high zone is a reworked or remodeled slope. It exhibits both transverse ridges and dune fields. In other words, the line that separates the residual and reworked slopes in the stoss slope shows at least two stages in the evolution of this draa. The first stage corresponds with the low zone. The entire stoss slope seems to be the result of a rhythmic balance between Aeolian deposition and deflation. The second stage corresponds to the high zone. A rupture in the advance of the transverse draa and the lack of sand supply seem to have interrupted the normal sedimentary balance in the stoss, producing a rework in its high part, in the crest and in the lee slope. Associated with the draa 1 , there is a linear dune in the northward projection of its northern end (Fig. 5). It is a sinuous chain, which crest line includes very frequent CHWs and some bifurcations, indicating a composition of reversing dunes.
In the second merger draa 2, the distinction between low and high stoss slope corresponds with a dichotomy a little different to that found in draa 1 . In the low zone, the residual features consist of transverse ridges, overlaid importantly by a field of transverse dunes. As these dunes mask the preexistent transverse ridges, their perception is difficult. Because of this type of superimposition (Table 1; Fig. 6), this landscape appears as an Aeolian palimpsest. Therefore, its residual character is only partial. Instead, the high zone is clearly the result of rework, showing an extended field of elongated upsiloidal dunes. The dichotomy in the stoss slope of this draa seems to correspond with the same types of rupture operating in the case of the draa 1. That is to say, ruptures in the advance of the transverse draa and in the normal sedimentary balance in the stoss.

On the other hand, the northward linear projection is a linear compound dune in a set of reverse elements, which generally contain Chinese walls, indicating an influence of SW, SE and S winds. 
Table 3. Envelope, Southeastern-facing: Properties of The Slopes.

Tabla 3. Envoltura, Cara suroriental: Propiedades de las vertientes.

\begin{tabular}{|c|c|c|c|c|}
\hline $\begin{array}{l}\text { Transverse } \\
\text { draa }\end{array}$ & Slope & Slope zone & $\begin{array}{l}\text { Transverse ridge type or dune } \\
\text { landforms }\end{array}$ & $\begin{array}{l}\text { Assumed } \\
\text { genesis }\end{array}$ \\
\hline \multirow{7}{*}{$\begin{array}{l}\text { 1: First } \\
\text { merger, } \\
\text { southwest } \\
\text { facing }\end{array}$} & \multirow[t]{7}{*}{ Stoss } & \multirow[t]{2}{*}{ Low: residual } & $\begin{array}{l}\text { East facing: forked, length of wave } \\
20 \mathrm{~m}\end{array}$ & $\begin{array}{l}\text { Elongated } \\
\text { upsiloidal }\end{array}$ \\
\hline & & & $\begin{array}{l}\text { Southeast facing: mega sinuous - } \\
\text { feathered }\end{array}$ & $\begin{array}{l}\text { Elongated } \\
\text { complex }\end{array}$ \\
\hline & & \multirow[t]{4}{*}{$\begin{array}{l}\text { High: reworked } \\
\text { or remodeled }\end{array}$} & Northern zone dune field & $\begin{array}{l}\text { Southwestern } \\
\text { elongated } \\
\text { upsiloidal }\end{array}$ \\
\hline & & & Central north dune zone & $\begin{array}{l}\text { Southwestern } \\
\text { elongated } \\
\text { barchans }\end{array}$ \\
\hline & & & Central south zone: simple, short wave & $\begin{array}{l}\text { Elongated } \\
\text { barchans }\end{array}$ \\
\hline & & & Southern zone: simple mega ridges & $\begin{array}{l}\text { Elongated } \\
\text { barchans }\end{array}$ \\
\hline & & Indifferent (high) & Southern zone: networked pattern & Nested dunes \\
\hline \multirow{2}{*}{$\begin{array}{l}\text { 2: Second } \\
\text { merger, south } \\
\text { facing }\end{array}$} & \multirow[t]{2}{*}{ Stoss } & $\begin{array}{l}\text { Low: residual and } \\
\text { reworked features }\end{array}$ & $\begin{array}{l}\text { Linear transverse overlaid by } \\
\text { transverse dunes }\end{array}$ & $\begin{array}{l}\text { Aeolian } \\
\text { palimpsest }\end{array}$ \\
\hline & & High: reworked & $\begin{array}{l}\text { Dune field: forked, feathered and } \\
\text { sinuous features }\end{array}$ & Upsiloidal \\
\hline
\end{tabular}

Northwestern facing system (Figs. 3 and 7; Tables 1 and 4)

This envelope zone is very different to that of the southwestern facing system. It is a complex dune set formed by reverse sinuous dunes, rock-core dunes, and a northward linear projection. The azimuths of the sinuous reverse dunes and the exposition of their slopes suggest the operation of principal wind NW, SE, NE, SW, N and S in the morphogenesis.

The crestlines are sharp, adopting the form of a Chinese wall. This feature presents some crest bifurcations enveloping funnels. The crest sinuosity suggests the effect of alternate reversing winds in the corresponding lengths of wave. As in the nucleus, the Chinese wall represents the influence of simultaneous convergent winds, without important difference between the stoss and lee slopes. In this system, the sinuous crestlines always contain a Chinese wall. That is to say, in this part of the envelope, the co-existence between these two features seems inherent to the steady state of the sinuosity.

On the part of the rock cored dunes, the orientations and the exposition of their slopes indicate the principal influence of the NE, SW, NNE and SSW winds. These types of dunes are located in some low parts of the system.

The northward linear projection suggests a sand drift fed by the periphery of the system. It is a linear compound dune consisting of a chain of parabolic dunes associated as a narrow aklé. Its morphology insinuates the predominance of SSW wind. 


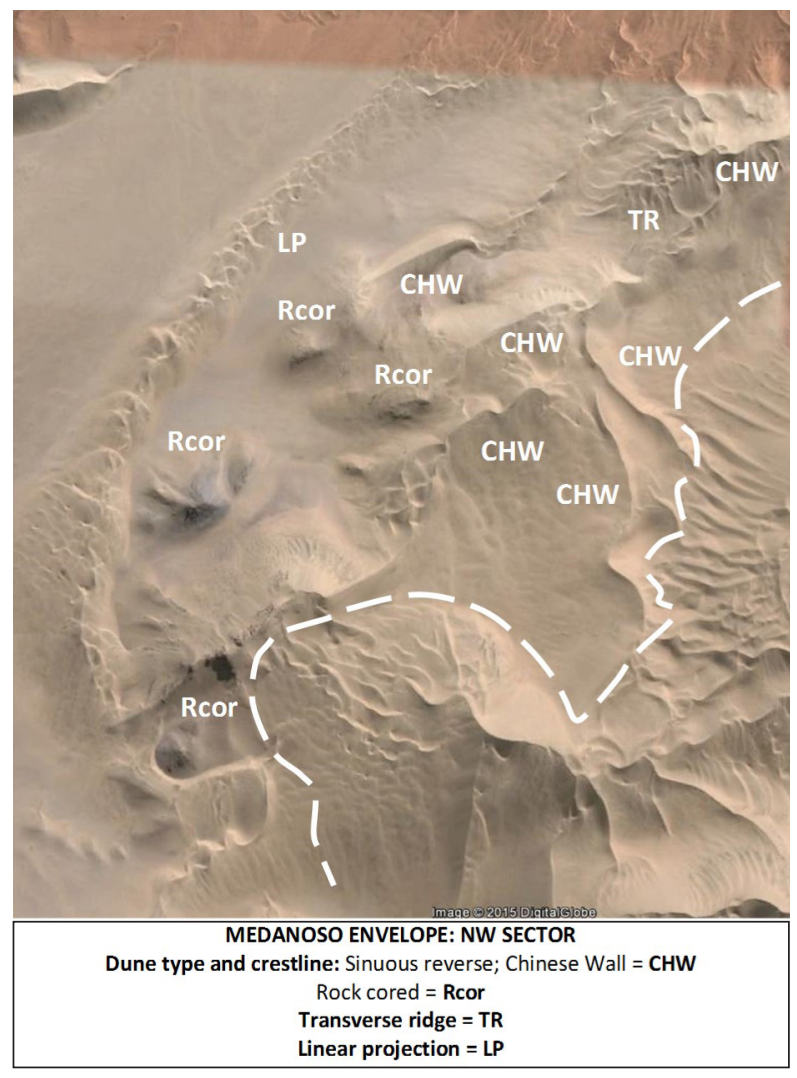

Fig. 4. Medanoso nucleus

Fig. 4. Núcleo del Medanoso

Table 4. Envelope, south west facing: Parts of dune complex Set.

Tabla 4. Envoltura, cara sudoccidental: Partes del Conjunto dunar complejo

\begin{tabular}{|c|c|c|c|c|c|c|}
\hline TYPE OF DUNE & $\begin{array}{l}\text { ORIENTATION } \\
\left.\text { (AZIMUTH }^{\circ}\right)\end{array}$ & $\begin{array}{c}\text { LENGTH / } \\
\text { MAX. WIDTH } \\
\text { (M) }\end{array}$ & $\begin{array}{c}\text { WIND } \\
\text { RELATED } \\
\text { SLOPES }\end{array}$ & $\begin{array}{c}\text { SINUOSITY } \\
\text { (WAVE } \\
\text { LENGTH, M) }\end{array}$ & $\begin{array}{l}\text { CRESTLINE: } \\
\text { DEGREE OF } \\
\text { SHARPNESS }\end{array}$ & $\begin{array}{c}\mathbf{N}^{\circ} \text { OF } \\
\text { FunNELS }\end{array}$ \\
\hline Sinuous reverse 1 & 290 & $721 / 165$ & $\mathrm{~N}-\mathrm{S}$ & 543 & Chinese wall & 0 \\
\hline Sinuous reverse 2 & 245 & $607 / 156$ & NW-SE & 152 & Chinese wall & 0 \\
\hline Sinuous reverse 3 & 350 & $665 / 214$ & E-W & 333 & Chinese wall & 1 \\
\hline Sinuous reverse 4 & 250 & $461 / 315$ & NW-SE & 230 & Chinese wall & 0 \\
\hline Sinuous reverse 5 & 250 & $382 / 337$ & NE-SW & 190 & Chinese wall & 1 \\
\hline Rock cored 1 & 50 & $193 / 119$ & NE-SW & - & - & - \\
\hline Rock cored 2 & 50 & $315 / 122$ & NE-SW & - & - & - \\
\hline Rock cored 3 & 60 & $325 / 268$ & NE-SW & - & - & - \\
\hline Rock cored 4 & 310 & $507 / 232$ & NNE-SSW & - & - & - \\
\hline $\begin{array}{l}\text { Northward linear } \\
\text { projection }\end{array}$ & 15 & $1904 / 355$ & SSW-NNE & - & - & - \\
\hline
\end{tabular}


The sand

The sample obtained in the envelope indicates that the sand is very fine-to-fine and well sorted (standard deviation 0.35 $-0.5)$. Its grain size distribution is almost symmetric, being the mode closely above the median (Fig. 8). The grains of quartz and lithic fragments are both rounded and sub rounded, but the roundness is higher in lithic particles. Nevertheless, both types of grain are highly polished. All the quartz sand presents ferric oxides, but only- in minor proportions- the color intensity (chroma) is relatively high (Table 5). The scarce feldspars and rhyolite glasses lack roundness, polish and oxidation. However, polish shine appears on some sub-angular glasses (Fig. 9; Table 5).

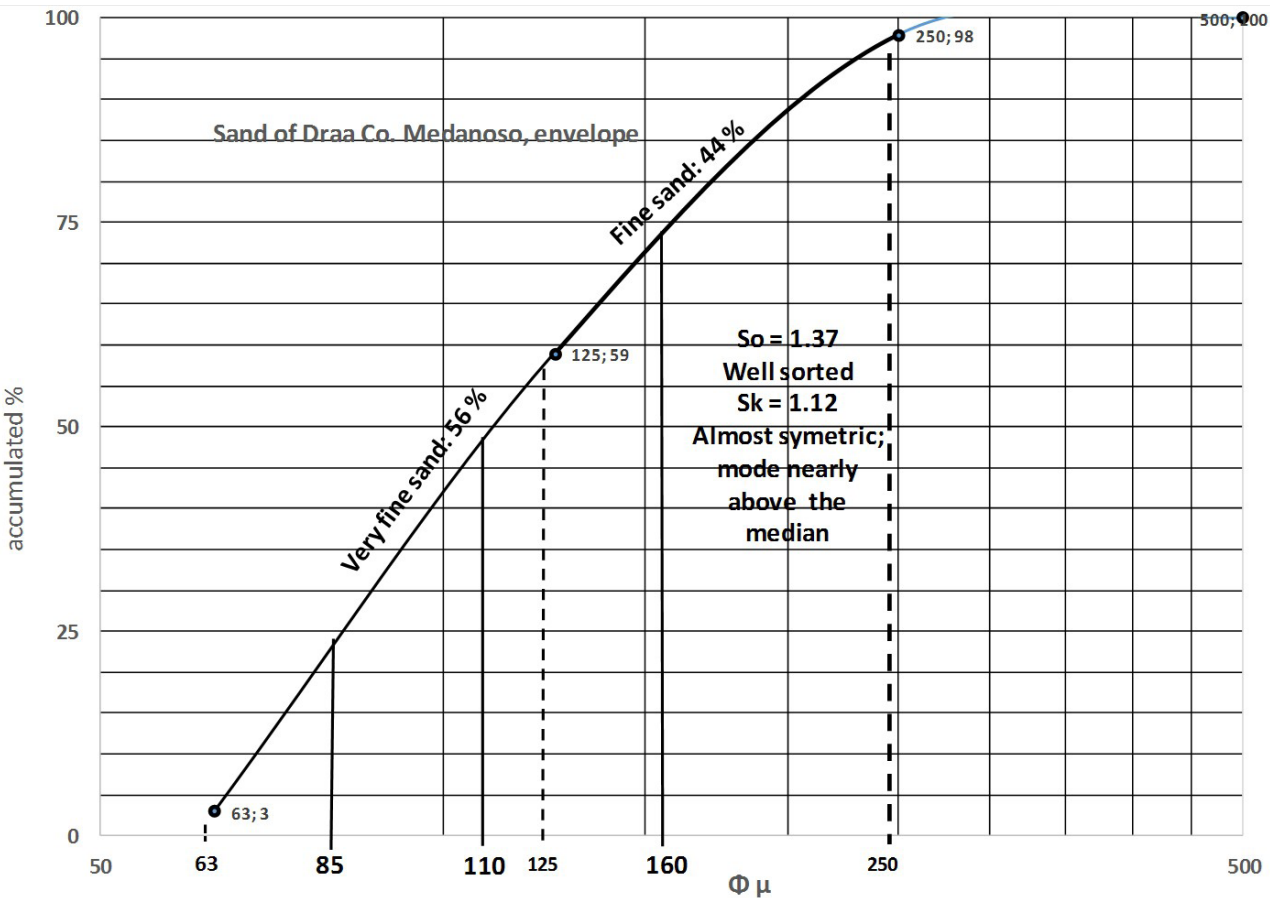

Fig. 8. Envelope 1: Proxy of sand granulometry

Fig. 8. Envoltura 1: Proxy de granulometría de arena 
TABLE 5. SAND PROPERTIES (OBSERVED GRAINS = 200)

Tabla 5. Propiedades de la arena (granos observados $=200$ )

\begin{tabular}{|c|c|c|c|c|c|c|}
\hline Lithology & $\begin{array}{l}\text { Approx. } \\
\%\end{array}$ & Roundness & $\begin{array}{l}\text { Polish } \\
\%\end{array}$ & $\begin{array}{l}\text { Showy } \\
\text { redness } \\
(\%)\end{array}$ & $\begin{array}{l}\text { Light } \\
\text { redness } \\
(\%)\end{array}$ & $\begin{array}{l}\text { Redness Rating, color } \\
R R=H^{*} \times V / C \\
H^{*}=\text { modified hue; } V=\text { value; } \\
C=\text { chroma. } \\
\text { Experienced scale }=8-61\end{array}$ \\
\hline General & & & & & & $\begin{array}{l}\text { For } 10 \mathrm{YR}, \mathrm{H}^{*}=20 \\
\mathbf{1 5} \\
\text { brownish yellow }\end{array}$ \\
\hline Quartz & 77 & $\begin{array}{l}\text { Rounded } \\
\text { - sub- } \\
\text { rounded }\end{array}$ & 100 & 15 & 85 & $\begin{array}{l}\text { For } 5 \mathrm{YR}, \mathrm{H}^{*}=15 \\
\text { High }=\mathbf{1 3} \text { (reddish yellow) } \\
\text { Low }=\mathbf{3 0} \text { (pinky) }\end{array}$ \\
\hline Feldspar & 4 & $\begin{array}{l}\text { Sub } \\
\text { angular } \\
\text { - sub } \\
\text { rounded }\end{array}$ & 0 & 0 & 0 & - \\
\hline Glass & 5 & $\begin{array}{l}\text { Sub } \\
\text { angular }\end{array}$ & 0 & 0 & 0 & - \\
\hline $\begin{array}{l}\text { Lithic- } \\
\text { Ferro- } \\
\text { Magnesium }\end{array}$ & 14 & Rounded & 100 & - & - & $\begin{array}{l}\text { For } 5 \mathrm{YR}, \mathrm{H}^{*}=15 \\
\text { General = } \mathbf{1 9} \\
\text { reddish brown }\end{array}$ \\
\hline
\end{tabular}

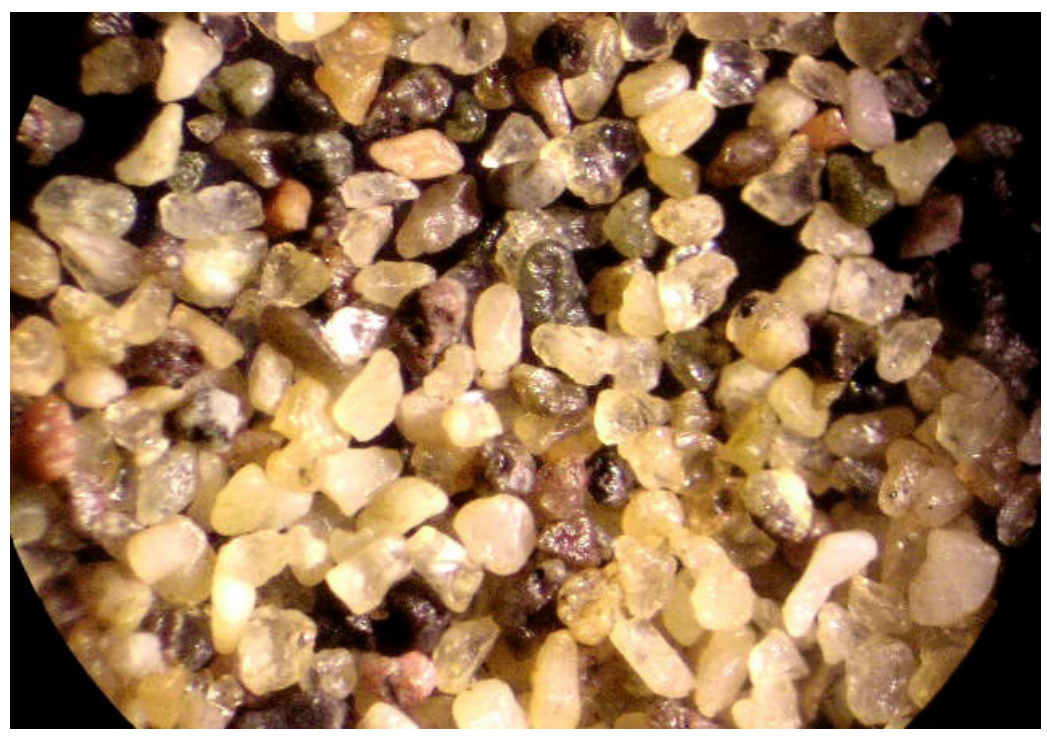

Fig. 9. Envelope 1: Proxy sand microscopic view

Fig. 9. Envoltura 1: Proxy de vista microscópica de arena 


\section{Sand magnetic properties}

The discrete and few precise determinations of magnetic sand by means of a 3500 gauss magnet indicates that at least $20 \%$ of the grains are magnetic. The actual quantity is probably greater. Because of the strong correlation between magnetic and heavy minerals (SHANKAR et al. 1996), this amount is a proxy of heavy sands. These grains are sub rounded, rounded and polished (Table 5).

\section{Analysis of the alluvial plain: glacis and desert pavement (Figs. 10-12)}

This analysis concerns the eastern piedmont of the Cerro Medanoso basin (Fig. 10). The proximal alluvial fans show desert pavement on their surfaces, the drainage net of which shows anastomosed channels. These present two degrees of incision. The principal channels of the proximal part are entrenched. In contrast, the downward talwegs of channels are superficial.

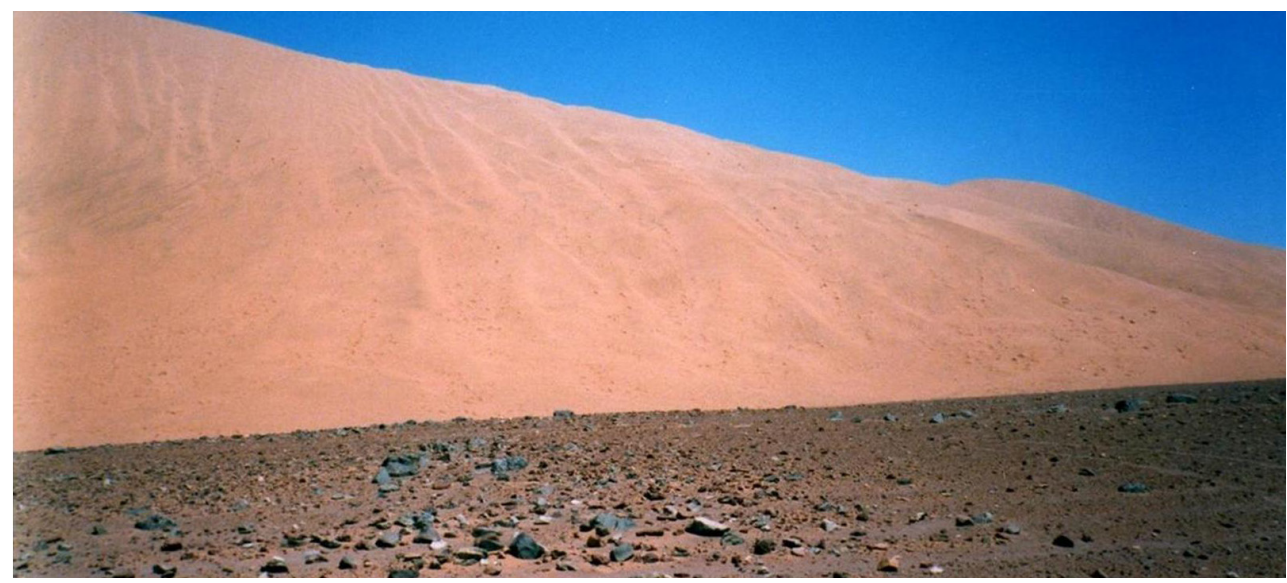

Fig. 10. Eastern glacis; contact with the draa and desert pavement

Fig. 10. Glacis oriental; contacto con el draa y pavimento de desierto

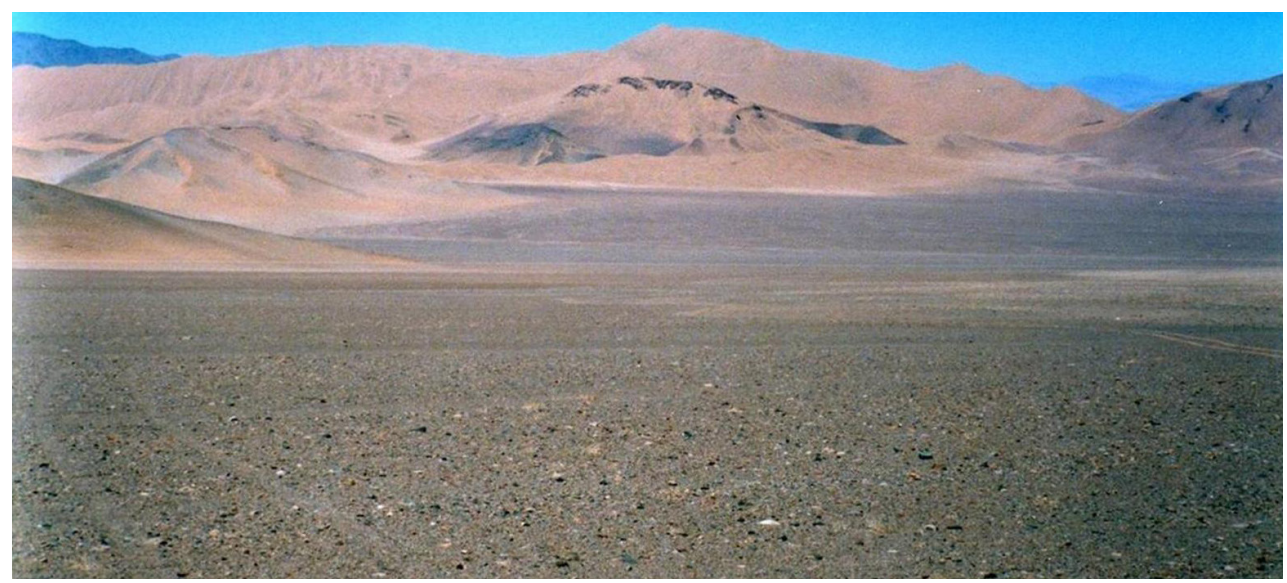

Fig. 11. Western glacis; contact with the draa and desert pavement

Fig. 11. Glacis occidental; contacto con el draa y pavimento de desierto 
The overflow glacis contains a very well developed desert pavement (Fig. 11). The anastomosed channels are shallow without incision. It merges with a distal glacis, the surface of which also contains desert pavement. The contact of this surface with the draa is sharp. The abundance of ventifacts in this feature indicates a strong and prolonged wind activity on it, but without present deflation of sand toward the draa.

In the boundary between the proximal and the distal glacis appear dunes of the parabolic family (Fig. 12), related with SSW formative winds. Their length decreases from South $(\sim 500-800 \mathrm{~m})$ to North $(\sim 70$ $160 \mathrm{~m}$ ). That is to say, from longitudinal and upsiloidal near the southern end to parabolic toward the northern end. This distribution seems related to the area of the overflow glacis, which decreases from South to North, as long as the length of the dunes. Therefore, the glacis seems to be the feeder of the dunes during a late phase of deflation over its surface. Nevertheless, these dunes seem inactive at present, and they do not reach the basal limit of the draa slope.

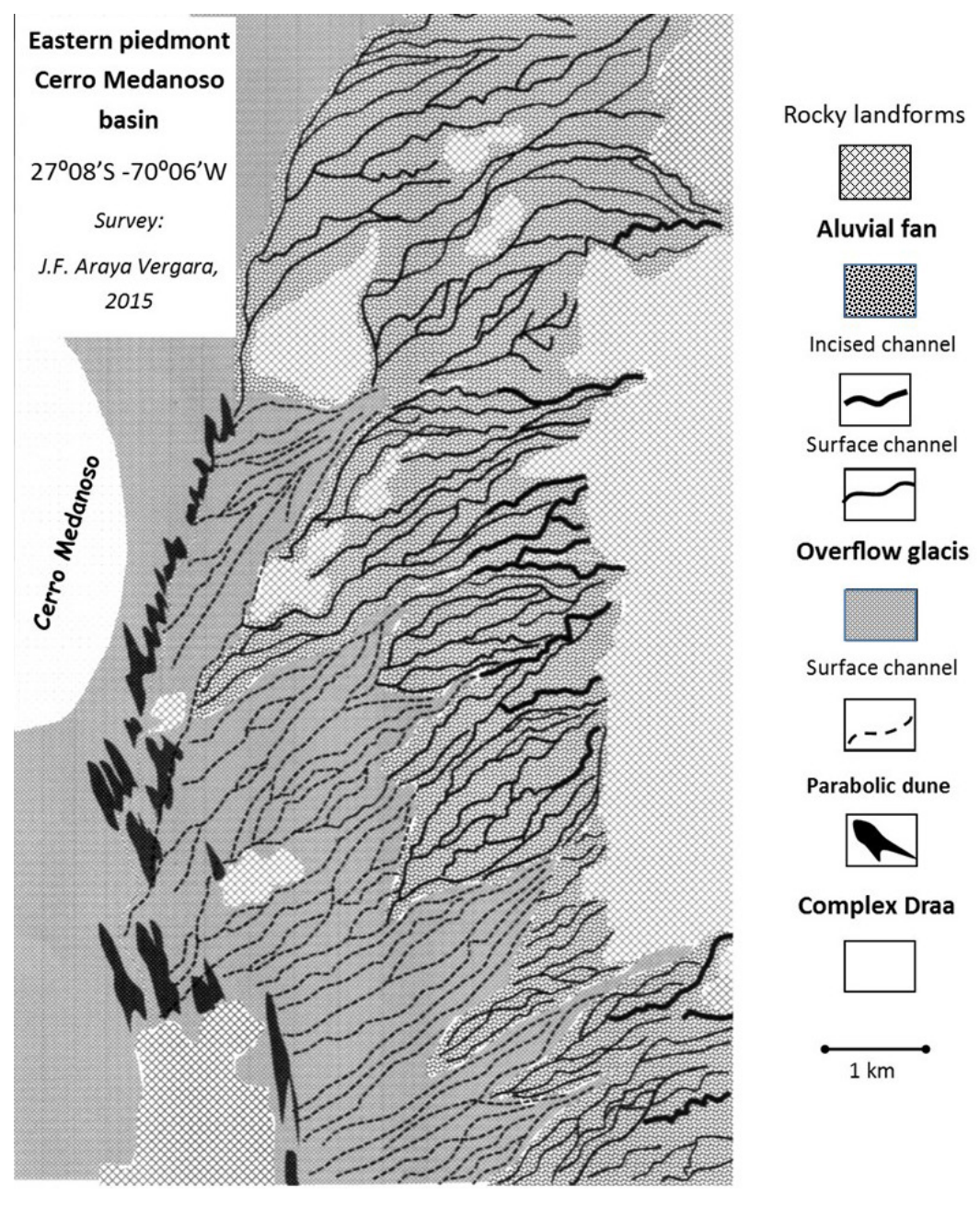

Fig. 12. Eastern piedmont geomorphology

Fig. 12. Geomorfología del piedmont oriental 


\section{DISCUSSION}

\section{Development of compound and complex dunes (Fig-13)}

The nucleus

An assessment of similar cases is very useful in order to analyze the compound star draa of this nucleus, . In the Grand Erg Oriental (Eastern Algeria, environs of Sif Fatima, $231^{\circ} 06^{\prime}$ N-8 $8^{\circ} 42^{\prime}$ E) the megadunes lack an envelope. The landscape among the draas essentially consists of sets of linear and sinuous dunes, the crestlines of which commonly contain Chinese walls, revealing that they are reverse dunes. Jointly, the compound nature of the star draas does not present clear indications of simultaneous or successive construction of the constituent stars. Each compound star has several arms. This suggests that the isolated growth of two neighboring stars was the cause of the linking between them. This association appears clearly in the dense stellate sets of the Gran Desierto de Altar (northwest of Sonoran Desert, Mexico), where the close and sometimes intricate linking between star arms is evident. Possibly, the nucleus of Cerro Medanoso had a similar origin.

On the other hand, in order to understand the dynamics of the star arm slopes, and taking into account that the study of the transverse Aeolian ridges (TARs) is important, their analysis rendered possible a genetic denomination of individual ridges. Because of their size order and morphology, these landforms have the elements of elongated upsilodal or barchan dunes. For them, the use of the genetic expression "slope dune ridges" instead of the non-genetic term "transverse Aeolian ridge" seems to be convenient. Actually, these features are not transverse to the wind, because they are longitudinal forms following the up-slope direction. In order to avoid conceptual ambiguities applied to these features, first steps of discussion are shown in the works of BOURKE et al. (2003) and ZIMBELMAN et al. (2013).

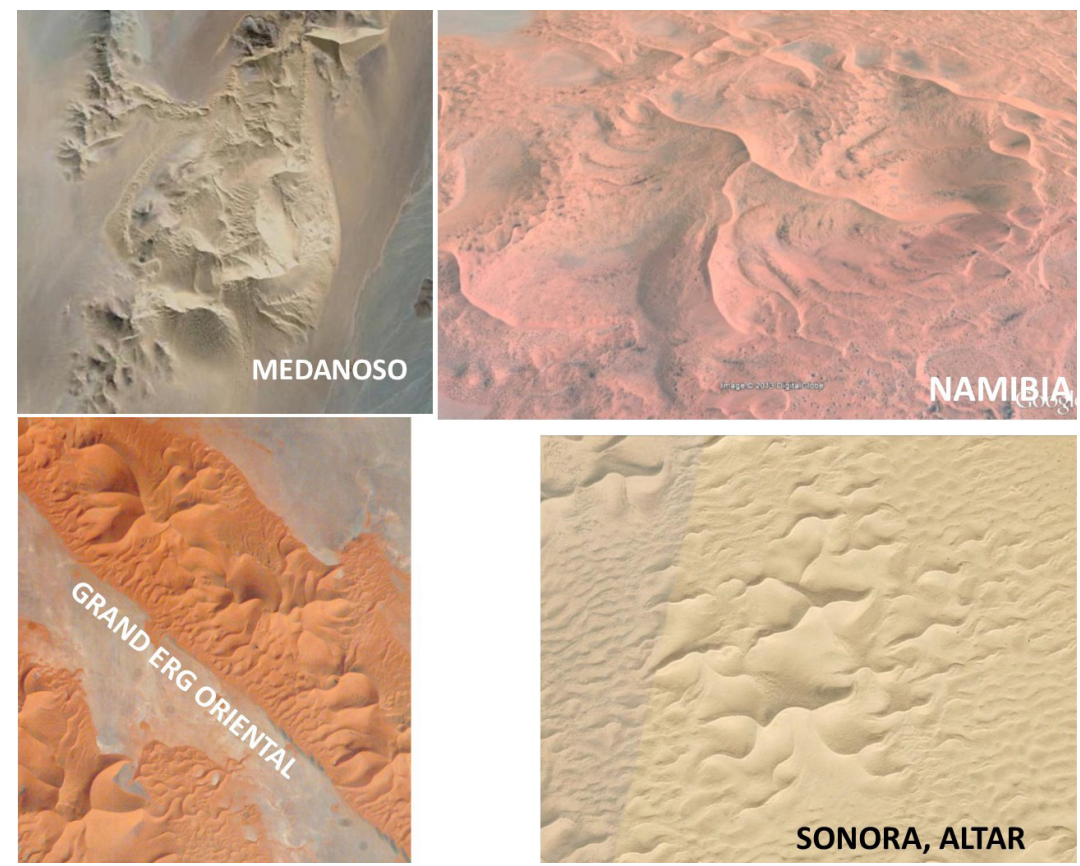

Fig. 13. Star draas: compared geomorphology

Fig. 13. Draas en estrella: geomorfología comparada 


\section{The envelope}

In order to understand the genesis of the envelope, the observation of some draa fields should be considered. In Namibia (Lüderitz region, East Naukluft Park, $\left.25^{\circ} 58^{\prime} \mathrm{S}-15^{\circ} 56^{\prime} \mathrm{E}\right)$ only embryonic features of an envelope appear consisting of sinuous dunes with Chinese walls. Some sinuous crestlines are associated with forming funnels. Actually, this set shapes a fringe around the star, but its inclusion of only reverse dunes makes the merging with the star draa difficult. In the Grand Erg Oriental (Sif Fatima sector), the landscape among compound stars shows sinuous landforms, which do not envelop these draas. On the part of the Gran Desierto de Altar (Sonoran Desert) the dense stellate set with closed and intricate linking between star arms impedes the possible vicinity of dunes other than stars. Therefore, the search for envelopes in the examined deserts indicates the lack of associations as that shown by Co. Medanoso. Nevertheless, the structure of the Namibia type fringe is visible in the northwest facing system of the Medanoso envelope.

Experiences compiled by ALLEN (1968 and 1984, in LANCASTER 1995) suggest that these landforms respond to temporal morphological changes. Other observations of GLENNIE (1970, in LANCASTER 1995) and BESLER (1980, in LANCASTER 1995) suggest that large dunes are product of Pleistocene glacial ages due to the influence of strong winds.

Concerning the relationships between the nucleus and the envelope, LANCASTER (1995) observed that in the Namibian Desert the superimposed dunes related with draas are transverse landforms, this coincides with the terms used by BRIDGE \& DEMICCO (2008).

In relation to the possible dynamics and migration of transverse draas, before the merging with the nucleus and the interruption of sand supply from the glacis, detailed field observations of WALKER \& SHUGAR (2013) include different wind effects affecting both the stoss and lee slopes. An empirical flow deflection model indicates directional variations related to lateral diversion of surface flows, starting from various incident wind angles over the stoss slope. The corresponding relationships include differential deflections of winds, related with the sand budget among the supply of sand of the glacis, the orientation of the stoss and the position of the lee in the transverse draa. Then, the application of the model on transverse dunes is useful for a hypothetical reconstruction of their dynamics and migration before their merging with the nucleus.

The model by WALKER \& SHUGAR (2013) shows the difference between the migration of the transverse draa and the mechanism of merging and post merging with the nucleus. Therefore, the merger draa 1 and 2 in SW envelope, the assumed rupture in the evolution of the stoss slope seems consubstantial with the process of merging. The degree of permanence of the deposition and erosion processes in this type of slope is inherent to the displacement of a mega dune. Consequently, the present high and low zones of the stoss slope seem to be the result of two thresholds: breaking of the dune migration due to merging with the nucleus and interruption of sand supply from the glacis.

\section{Sands}

In spite of the discrete character of the sample, the analytical results indicate evolutionary cycles of the sand. For the quartz and lithic grains the successive states are roundness, oxidation and polish. The degree of roundness of the grains precedes the formation of the ferric coating, which is adapted to the form of the grain. As the oxidation does not produce brightness, the polished ferruginous surface of quartz and lithic grains appeared recently when they 
abandoned the oxidant environment. Their brightness seems to have been acquired by hydric and eolian combined actions, both during the piedmont formation and the subsequent wind deflation. Therefore, it is possible that these sands arise from distant basins.

\section{Desert pavement}

The interpretations of BRÜGGEN (1951) and BAILEY et al. (2007) use the classic scheme, which indicates that the desert pavement results from the gradual removal of sand, silt and clays by the wind and intermittent rains, leaving the gravels behind. The removal of fine sediments operates until the formation of the pavement, because it protects the underlying fine particles, resisting their further erosion. These processes are evident also in the pavement of the Cerro Medanoso basin, because of the presence of ventifacts and residual sands. Moreover, the discrimination of fluvial and eolian features (BAILEY et al. 2007), the discussion by CLARKE (2006) and observations on alluvial fans (HARTLEY et al. 2005) indicate that the Atacama Desert is very old. In the Cenozoic, both Neogene and Quaternary landforms show climatic oscillations of a constant hyper-arid region.

\section{CONCLUSIONS}

The genesis of the complex Cerro Medanoso draa seems to be the product of the following formative pulses: construction of a stellate nucleus, merging of the eastern envelope, merging of the southern envelope and merging of a complex or polycyclic western envelope. In the envelope, there is a strong difference between the southeastern and northwestern facing systems. The southeastern facing system is much greater than the northwestern one. Consequently, the construction of the complex draa is asymmetric. The correlation of this megadune with similar star and compound draas to other deserts in the world indicates that the closest analogue exists in Namibia, but without merging signals between the envelope and the nucleus. Other star draas observed in the world exhibit a lack of envelope.

Regarding the neighboring piedmont, the beginning of its deflation seems necessarily correlative to the initial construction of the twin star draa. The later deflation may be responsible of the posterior pulses, which formed the envelope. The greater volume of the southwestern envelope, suggests that the principal mass of sand was supplied by the eastern glacis.

Therefore, the neighboring desert pavement and the different parts the draa are correlative landforms, which represent a very long formation time in an important part of desert Quaternary history, as evidenced by the cited and referenced research works.

\section{ACKNOWLEDGMENTS}

The authors are grateful for the invitation and support of the Regional Ministerial Secretary (Atacama Region), Architect Daniel Sepúlveda, the Geogr. Marcela Luci and the staff of the Ministerial Secretary's Office. Altogether, several members of the regional raid associations rendered possible, and with gentility, the access toward the field of dunes and draa.

\section{REFERENCES}

ARAYA-VERGARA, J.F. (2001). Los ergs del desierto marginal de Atacama, Chile. Investigaciones Geográficas, 35, 27-66.

BAILEY, J.E., STEPHEN, S., WOOLLER, L.K. \& MOUGINISMARK, P.J. (2007). Discrimination of fluvial and eolian features on large ignimbrite sheets around La Pacana Caldera, Chile, using Landsat and SRTM-derived DEM. Remote Sensing of Environment, 108, 24-41. 
BEVERIDGE， C., KOCUREK, G., EWING, R.C., LANCASTER, N., MORTEKAI, P., SINGHVI, A.K., \& MAHAN, S.A. (2006). Development of spatially diverse and complex dune-field patterns: Gran Desierto Dune Field, Sonora, Mexico. Sedimentology, 53, 1391-1409.

BOURKE, M.C., WILSON, S.A., \& ZIMBELMAN, J.R. (2003). The variability of transverse aeolian ridges in troughs on Mars. Lunar and Planet. Sci., 24, Abstract 2090.

BRIDGE, J.S. \& DEMICCO, E.V. (2008). Earth surface processes, landforms and sediment deposits. Cambridge Univ, Press, N.Y.

BOURKE, M.C., EWING, R.C., FINNEGAN D. \& MC GOWAN, H.A. (2009). Sand dune movement in the Victoria Valley, Antarctica. Geomorphology, 109, 3-4. http://dx.doi.org/10.1016/j. geomorph.2009.02.028

BRISTOW, C.S., AUGUSTINUS, P.C., WALLIS, I.C., JOL, H.M., \& RHODES, E.J. (2010). Investigation of the age and migration of reversing dunes in Antarctica using GPR and OSL, with implications for GPR on Mars. Earth Planet. Sci. Letters, 289, 30-42. http://dx.doi.org/10.1016/j. eps1.2009.10.026

BRÜGGEN, J. (1951). Las costras de protección en los desiertos. R. Universitaria, 36(1), 101-104.

BUBENZER, O. \& BOLTEN, A. (2008). The use of new elevation data (SRTM/ASTER) for the detection and morphometric quantification of Pleistocene megadunes (draa) in the eastern Sahara and the southern Namibia. Geomorphology, 102, 221-231. http://dx.doi.org/10.1016/j. geomorph.2008.05.003
BULLARD, J.E., THOMAS, D.G.S., LIVINGSTONE, I., \& WIGGS, I. (1995). Analysis of linear sand dune morphological variability, southwestern Kalahari Desert. Geomorphology, 11, 189-203. http://dx.doi. org/10.1016/0169-555X(94)00061-U

CLARKE, J.D.A. (2006). Antiquity and aridity in the Chilean Atacama Desert. Geomorphology, 73, 101-114. http://dx.doi. org/10.1016/j.geomorph.2005.06.008

COMPTON, R.R. (1962). Manual of field geology. Wiley, N. York.

HARTLEY, A.J., MATHER, A.E., JOLLEY, E., \& TURNER, P. (2005). Climatic controls on alluvial-fan activity, Coastal Cordillera, Northern Chile. Geological Society, London. Special Publications, 251, 95-115.

HAUG, E.W., KRAAL, E.R., SEWALL, J.O., VAN DIJK, M., \& CHONG DÍAZ, G. (2010). Climatic and geomorphic interactions on alluvial fans in the Atacama Desert, Chile. Geomorphology, 121, 184196.

HURST, V.J. (1977). Visual estimation of iron in saprolite. Geol. Soc. Amer. Bull., 88(2), 174-176.

KOCUREK, G. \& EWING, R.C. (2005). Aeolian dune field self-organization implications for the formation of simple versus complex dune-field patterns. Geomorphology, 72, 94-105. http://dx.doi. org/10.1016/j.geomorph.2005.05.005

KRUMBEIN, W.C. \& PETTIJOHN F.J. (1938). Manual of sedimentary petrography. Appleton, N. York.

LANCASTER, N. (1988). Controls of eolian dune size and spacing. Geology, 16, 972-975. 
LANCASTER, N. (1989). The dynamics of star dunes: an example from the Gran Desierto, Mexico. Sedimentology, 36, 273 289.

LANCASTER, N. (1995). Geomorphology of desert dunes. Routledge, London.

LANCASTER, N. (2004). Draa (Megadune). In: Goudie, A. (Ed.), Encyclopedia of Geomorphology. Routledge Ltd., N. York.

LÓKI, J. \& CSERHÁTI, C. (2006). The examining quartz grains of sedimentary rocks by scanning electron microscope. Annales Geographicae, 39(1), 42-51.

\section{LUCKE, B., KEMNITZ H., BÄUMLER} R. \& SCHMIDT, M. (2014). Red Mediterranean Soils in Jordan: New insights in their origin, genesis and role as environmental archives. Catena, 112, 4-24. http://dx.doi.org/10.1016/j. catena.2013.04.006

MOUNTNEY, N. (2003). Aeolian Environments. Lecture Layout.

MOUNTNEY, N. \& HOWELL, J. (2000). Aeolian architecture, bedform climbing and preservation space in the Cretaceous Etjo Formation, NW Namibia. Sedimentology, 47, 825-849. http://dx.doi.org/10.1046/ j.1365-3091.2000.00318.x

NGUER, M. \& ROGNON, P. (1989). Homogénéité des caractères sédimentologiques des sables ogoliens entre Nouaukcott (Mauritanie) et Mbour (Sénégal). Géodynamique, 4(2), 119-133.

NIELSON J. \& KOCUREK, G. (1987). Surface processes, deposits, and development of star dunes: Dumont dune field, California. Geol. Soc. Amer. Bull., 99(2), 177-186.
PETTIJOHN, F.J., POTTER, P. \& SIEVER, P. (1972). Sand and Sandstone. Springer Verlag, N. York.

POWERS, M.J. (1953). A new roundness scale for sedimentary particles. J. Sediment. Res., 23(2), 117-119. doi: $\quad$ 10.1306/D4269567-2B26-11D7$8648000102 \mathrm{C} 1865 \mathrm{D}$

SEGERSTROM, K. (1967). Geology and ore deposits of Central Atacama Province, Chile. Geol. Soc. Amer. Bull., 78, 305-318.

STEFAN, C. (2007). World Atlas of sands. Wordpress template by Jinsona.

SHANKAR, R., THOMPSON, R. \& PRAKASH, T.N. (1996). Estimation of heavy and opaque mineral contents of beach and offshore placers using rock magnetic techniques. Geo-Mar. Lett. 16(4), 313- 318.

SOUTENDAM, C.J.A. (1967). Some methods to study surface textures of sand grains. Sedimentology, 8, 281-290.

WALKER, I.J. \& SHUGAR, D.H. (2013). Secondary flow deflection in the lee of transverse dunes with implication for dune morphodynamics and migration. Earth Surf. Process. Landforms, 38(14), 1642-1654. http://dx.doi.org/10.1002/esp.3398

WARREN, A. (2013). Dunes: dynamics, morphology, history. J. Wiley \& Sons, Chichester.

WARREN, A. \& ALLISON, D. (1998=). The palaeoenvironmental significance of dune size hierarchies. Palaeogeogr., Palaeoclim., Palaeoecol., 137, 289303. http://dx.doi.org/10.1016/S00310182(97)00110-7

WERNER, B.T. (1995). Eolian dunes: computer simulations and attractor interpretation. Geology, 23, 11071110. http://dx.doi.org/10.1130/00917613(1995)023<1107:EDCSAA > 2.3.CO;2 
WILSON, I.G., (1972). Aeolian landforms - their development and origin. Sedimentology, 19, 173-210.

ZIMBELMAN, J.R. (2010). Transverse Aeolian ridges on Mars: First results from HiRISE images. Geomorphology, 121, 20-29. http://dx.doi.org/10.1016/j. geomorph.2009.05.012
ZIMBELMAN, J.R., BOURKE, M.C. \& LORENZ, R.D. (2013). Recent development in planetary Aeolian studies and their terrestrial analogs. Aeolian Res., 11, 109-126. http://dx.doi.org/10.1016/j. aeolia.2013.04.004 